\section{Association Between -1607 1G/2G Polymorphism of $M M P 1$ and Temporomandibular Joint Anterior Disc Displacement with Reduction}

Alberto Sierra Rosales ${ }^{1} \oplus$, Eduardo Alberto Villaseñor Rodríguez ${ }^{2} \oplus$, Christian

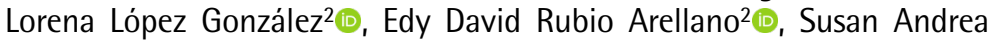
Gutiérrez Rubio²@, Teresa Arcelia García Cobián² [0
'Departamento de Clínicas Odontológicas Integrales, Centro Universitario de Ciencias de la Salud, Universidad de Guadalajara ${ }^{2}$ Instituto de Terapéutica Experimental y Clínica, CUCS Centro Universitario de Ciencias de la Salud; Universidad de Guadalajara

Correspondence: Teresa Arcelia García Cobián, Centro Universitario de Ciencias de la Salud, Edificio P primer Piso, Sierra Mojada 950, Col. Independencia CP 44340 Guadalajara, Jalisco, Mexico. Tel: +33-10-58-52-00. e-mail: tgcobian2002@yahoo.com.mx

Key Words: temporomandibular disorder, anterior disc displacement, single nucleotide polymorphism, matrix metalloproteinase, $\mathrm{mmp}-1$

\section{Introduction}

Temporomandibular disorders (TMD) encompass a group of musculoskeletal and neuromuscular conditions that include the temporomandibular joints (TMJ), the masticatory muscles and all associated tissues (1).

These disorders impact approximately $5-12 \%$ of the general population in the United States (2). Recent studies report the prevalence among adolescents in other nations between $9.0 \%$ and $48.7 \%$, according to the Research Diagnostic Criteria for Temporomandibular Disorders (RDC/ TMD) (3).

The most common subtypes of TMDs include painrelated disorders, such as myofascial pain, arthralgia, and disorders associated with the TMJ, primarily internal derangements, degenerative joint disease, including associated biopsychosocial conditions $(4,5)$.

Internal derangements are defined as deviations in the position or form of the tissues within TMJ capsule; DDWR occurs when the articular disc is anteriorly displaced relative to the condylar head in the closed mouth position and restores (reduces) its normal physiological relation with the affected condyle during mouth opening, the disc reduction is usually accompanied by articular noises (6). DDWR is the most common internal derangement encountered in adults and corresponds to 41\% of TMD clinical diagnoses (7).

Anterior disc displacement without reduction (ADDwoR) is present when the disc is unable to return to its normal position, which leads to a decrease in mouth opening and is usually painful (8). In a study of prevalence and associated factors conducted in Mexico, at the University of Campeche with 506 patients aged 14-25 years, at least $46.1 \%$ of patients had some grade of TMD, while anterior disc displacement with reduction was the most prevalent with $15.6 \%$ (9).

The articular disc of the TMJ is formed basically by proteoglycan aggregates and collagen fibers that are composed mainly of type 1 and 2 collagen; its physiologic maintenance is through a balance between degradation of collagen fibers performed by matrix metalloprotease (MMP) and their inhibitors, tissue inhibitors of metalloproteinase (TIMP) $(10,11)$. An association has been reported between accelerated collagen degradation and the increased production and overexpression of MMP1 in the synovial fluid of the TMJ of patients with osteoarthritis (12-14).

Previous functional studies have reported the -1607 $1 \mathrm{G} / 2 \mathrm{G}$ polymorphism of MMP1 gene leads to an increase in local MMP1 concentration, which contributes to accelerated degradation of the extracellular matrix $(15,16)$. 
In 2011, Planello found an association between the MMP1 polymorphism and degenerative disorders of the TMJ in patients who had been diagnosed using magnetic resonance (17). Luo et. al. (18), for their part, found an association between this polymorphism and ADDwoR in patients with and without temporomandibular osteoarthritis. Many proteins constitute the TMJ of which type 1 collagen is one of the main components of the joint and, is mostly degraded by type 1 metalloproteinase. Patients with the MMP1 -1607 2G/2G genotype, included in this study, could manifest increased concentrations of MMP1, leading to a higher degradation of collagen and, potentially have an increased risk for developing DDWR. For this reason, the objective of our study was to evaluate the association between the $1607 \mathrm{G} / 2 \mathrm{G}$ polymorphism of MMP1 gene and DDWR in a group of Mexican individuals from western Mexico.

\section{Material and Methods}

This study was conducted in a group of 67 unrelated Mexican individuals from the western region of the country, between the ages of 18 and 36 years, of both genders, from 2013-2019. Every participant was required to sign an informed consent form with approval of the University of Guadalajara Committees (Conbioetica14cei01920130619); participants were selected and clinically evaluated by an expert Prosthodontist based on the Research Diagnostic Criteria for Temporomandibular Disorders (RDC/TMD) (19).

A control group of 90 individuals from the same region, without TMD, was also included. Both groups were of Mexican ancestry and without a history of facial trauma, unrelated, without association with any syndrome. The sample size was calculated with the formula for comparison of two independent proportions regard to the anterior disc displacement of the temporomandibular joint prevalence, which is within 18 to $36 \%$ (20). It was considered a confidence level of $95 \%$, a statistical power of $80 \%$. According to this, we needed 82 participants nevertheless 157 participants were included.

\section{Extraction and analysis of genomic deoxyribonucleic acid (gDNA)}

After informed written consent was obtained from the participants, $6 \mathrm{~mL}$ of peripheral blood was drawn from the forearm using tubes with ethylenediaminetetraacetic acid (EDTA), for the extraction of gDNA.

The extraction of gDNA was carried out using the modified Miller technique and the Genomic DNA Purification Kit (Promega, 2014) on total leucocytes (21). The 1607 1G/2G (rs1799750) single nucleotide polymorphism (SNP) of the MMP1 gene was amplified using nested PCR to determine the insertion-deletion. The first round of amplification was conducted using 5'GGAGTCACTCAGTGGCA3' (forward) and $5^{\circ}$ 'САСАСТTСССТСССТT $3^{\prime}$ (reverse) primers in a volume of $10 \mu \mathrm{L}$, containing $3 \mu \mathrm{L}$ of Master Mix (Promega Corporation), $0.4 \mu \mathrm{L}$ of each oligonucleotide $(0.1 \mathrm{pm} / \mu \mathrm{L}), 0.1$ $\mu \mathrm{L}$ of Taq polymerase, $4.6 \mu \mathrm{L}$ of deionized water and $1.5 \mu \mathrm{L}$ of gDNA; PCR was carried out, elevating the temperature of the mix for 5 min to $94^{\circ} \mathrm{C}$ for the initial denaturation, followed by 30 cycles of denaturation at $94^{\circ} \mathrm{C}$ for $30 \mathrm{~s}$, an alignment at $52{ }^{\circ} \mathrm{C}$ for $30 \mathrm{~s}$, an extension at $72^{\circ} \mathrm{C}$ for $30 \mathrm{~s}$ and a final extension at $72^{\circ} \mathrm{C}$ for $10 \mathrm{~min}$.

Subsequently, an aliquot of $2 \mu \mathrm{L}$ of the first PCR was amplified using the following primers 5 'GGAAATTGTAGTTAAATAATTAGAAAGA3' (forward), 5 'GATTGATTGAGATAAGTCATATCC3' (reverse), under the conditions described above.

Lastly, the amplified fragments were subjected to electrophoresis in a $6 \%$ polyacrylamide gel using a buffer solution (0.5x TBE), at 170-200 volts for $30-60$ $\mathrm{min}$, and the gel was stained with $0.2 \%$ silver nitrate. The amplified products obtained were 138 and 279bp for the $1 \mathrm{G} / 1 \mathrm{G}$ homozygote, 279,138 and $192 \mathrm{bp}$ for the $1 \mathrm{G} / 2 \mathrm{G}$ heterozygote and 192 and $279 \mathrm{bp}$ for the $2 \mathrm{G} / 2 \mathrm{G}$ homozygote. The samples were documented with a key and until statistical analysis, they were identified as case or control.

\section{Statistical Analysis}

Gene counting was used to determine allele and genotype frequency. The Hardy Weinberg equilibrium estimation and association analysis were calculated by chi-square, Fisher exact test and logistic regression, using a Finetti test program at ing.gsf.de/cgi-bin/hw/hwa1.pl and IBM-SPSS v20.

\section{Results}

The DDWR group was comprised of 47 women and 20 men, who were single and between the ages of 18-36 years (mean $=21.43 \pm 3.163$ years). $58.5 \%$ of these patients reported facial pain, 55.4\% had nocturnal and daytime bruxism, 72.3\% presented jaw locking, 78.5\% reported headache or migraine and $47.7 \%$ reported tinnitus (Table 1).

With respect to the genotypic frequency of the polymorphism in cases, the most frequent genotype associated with DDWR was $1 \mathrm{G} / 2 \mathrm{G}$ (68.7\%), followed by $2 \mathrm{G} / 2 \mathrm{G}(25.4 \%)$ and $1 \mathrm{G} / 1 \mathrm{G}(6.0 \%)$. The most frequent genotypes observed in the control group were $1 \mathrm{G} / 2 \mathrm{G}$ in $55.5 \%, 1 \mathrm{G} / 1 \mathrm{G}$ in $26.6 \%$ and $2 \mathrm{G} / 2 \mathrm{G}$ in $17.7 \%$. The $2 \mathrm{G}$ allele was most prevalent in the experimental group (Table 2).

The comparison with Fisher's exact test showed a significant difference $(p<0.001)$ between the affected group and the control group, as well as between the patients and the 1000 genome project $(p<0.001)$. Differences were also 
observed between wild type homozygous and heterozygous groups ( $p=0.001$ with an OR of 5.520) as well as regard to homozygous ( $p=0.0022$ with an OR of 6.375 ) and in dominant model comparison $(p=0.00081)$ with an $O R$ of 5.727. When comparing Mexican descendants of the 1000 genome project with the patients in our study, similar results were observed (Table 2).

No association was observed between the polymorphism and the presence of facial pain, jaw locking, bruxism, tinnitus or headache.

\section{Discussion}

Internal derangements of the TMJ are defined as deviations in the position and shape of the tissues within the capsule, and anterior disc displacement with reduction is considered one of the most common of these disorders (7). This condition is generally stable, painless and causes little to no discomfort for the patient (22), however,

Table 1. Clinical characteristics within a group of patients with anterior disc displacement with reduction

\begin{tabular}{|c|c|c|}
\hline Clinical Characteristics & Cases & Percent \\
\hline Facial Pain & 38 & $58.5 \%$ \\
\hline Headache & 51 & $78.5 \%$ \\
\hline Opening Limitation & 23 & $35.4 \%$ \\
\hline Jaw Locking & 47 & $72.3 \%$ \\
\hline Nocturnal Bruxism & 36 & $55.4 \%$ \\
\hline Daytime Bruxism & 36 & $55.4 \%$ \\
\hline Tinnitus & 31 & $47.7 \%$ \\
\hline
\end{tabular}

previous studies have shown that individuals with the $2 \mathrm{G} / 2 \mathrm{G}$ genotype could potentially develop degenerative disorders $(17,18)$.

As reported by the literature, the prevalence of TMD varies according to age and the population being studied, hence, the global prevalence of these disorders among adolescents has been reported in $9.0 \%$ to $47.7 \%$ (3). The presence of signs and symptoms has been observed in $16 \%-88 \%$ of the general population (23). In Mexico, Casanova-Rosado et. al. (9) conducted a study in 506 Mexican individuals from the southeast region of the country, between the ages of 14 to 25 years, and observed that $46.9 \%$ had a TMD. They determined that DDWR was the most common TMD found in $15.6 \%$ and that the prevalence was higher among women (52.9\%) than men $(27.9 \%)$ with an average age of $17.6 \pm 2.9$ years.

A greater influx of women was observed in our study, which was to be expected given that, on average, TMD occurs anywhere from 1.2 to 2.6 times more in women than in men, with women being on average two-fold risk to suffer from this condition than men (24). However, since this study was open to the general population, no frequency can be assumed, nevertheless more than half of our participants (70.1\%) were women.

Pain is a frequent symptom in these temporomandibular conditions $(5,24,25)$. Luo et. al. reported that $100 \%$ of their patients suffered from facial pain, with $71.6 \%$ reporting their pain as mild, while $24.9 \%$ reported it as moderate and 3.5\% as severe (18). For their part, Planello et. Al (17). observed that the prevalence of pain was $73.9 \%$, which coincides with the current study in which $58.5 \%$ of patients (38 cases) reported facial pain.

The frequency of bruxism in existing literature

Table 2. Distribution of genotypes, alleles, observed differences and the relative risk between cases, controls and the 1000 genome project

\begin{tabular}{|c|c|c|c|c|c|c|c|}
\hline \multirow{2}{*}{$\begin{array}{l}\text { Polymorphism } \\
-1607 \text { 1G/2G } \\
\text { Group }\end{array}$} & \multicolumn{4}{|c|}{ Genotypes n (\%) } & \multicolumn{2}{|r|}{ Alleles n (\%) } & \multirow{2}{*}{ Total } \\
\hline & $1 \mathrm{G} / 1 \mathrm{G}$ & $1 \mathrm{G} / 2 \mathrm{G}$ & $2 \mathrm{G} / 2 \mathrm{G}$ & $1 G / 2 G+2 G / 2 G$ & $1 \mathrm{G}$ & $2 \mathrm{G}$ & \\
\hline Cases & $4(6.0)$ & $46(68.7)$ & $17(25.4)$ & 63 & $\begin{array}{c}54 \\
(40.3)\end{array}$ & $80(59.7)$ & 67 \\
\hline Controls & $\begin{array}{c}24 \\
(26.6)\end{array}$ & $50(55.5)$ & $16(17.7)$ & 66 & $\begin{array}{c}98 \\
(54.4)\end{array}$ & $82(45.6)$ & 90 \\
\hline Chi-square (p) & ref & $10.19(0.001)$ & $9.30(0.002)$ & $11.23(<0.001)$ & ref & $6.15(0.013)$ & $\begin{array}{c}7.93 \\
(0.004)\end{array}$ \\
\hline OR (CI 95\%) & 1 & $\begin{array}{c}5.520[1.780- \\
17.117]\end{array}$ & $\begin{array}{c}6.375 \text { [1.809- } \\
22.465]\end{array}$ & $\begin{array}{c}5.727 \text { [1.881- } \\
17.437]\end{array}$ & 1 & $1.771[1.126-2.785]$ & 2.358 \\
\hline 1000 genomes & $\begin{array}{c}27 \\
(42 \%)\end{array}$ & $28(43.75)$ & $9(14.06)$ & $37(57.81)$ & $\begin{array}{c}82 \\
(64.06)\end{array}$ & 46 (35.93) & 64 \\
\hline Chi-square (p) & ref & $21.25(<0.001)$ & $\begin{array}{c}16.74 \\
(<0.001)\end{array}$ & $23.77(<0.001)$ & ref & $14.81(<0.001)$ & $\begin{array}{c}17.05 \\
(<0.001)\end{array}$ \\
\hline OR (CI 95\%) & 1 & 11.08 [3.510-35.035] & $\begin{array}{c}12.75 \text { [3.389- } \\
47.964]\end{array}$ & $\begin{array}{c}11.49 \text { [3.728- } \\
35.430]\end{array}$ & 1 & $2.641[1.603-4.352]$ & 3.430 \\
\hline
\end{tabular}


varies from $22-31 \%$ (26), which was very different from observations in the current study in which $55.4 \%$ of patients reported nocturnal and daytime bruxism and $72.3 \%$ reported jaw locking. The increased frequency of these complications could be due to increased occupational stress, given that the participants of this study were medical and dentistry students, with long hours of studying and who are prone to sleepless nights and are generally less physically active.

There is a high prevalence of otologic signs and symptoms among adult patients with TMD, which could be explained by different theories such as the proximity of the structures to the TMJ, the ear canal and the shared innervation. The results of a meta-analysis showed that the most frequent symptoms were blocked ear sensation $(74.8 \%)$, otalgia (55.5\%), tinnitus (52.2\%), vertigo (40.8\%) and hearing loss $(38.9 \%)$, which is similar to those found in our study in which $47.7 \%$ of patients reported hearing noises or buzzing in their ears (27).

The $-16071 \mathrm{G} / 2 \mathrm{G}$ SNP has also been shown to increase the expression, transcription, and activity of collagenase, which could potentially be associated with the severity of the condition from its onset (15). Two previous studies carried out in Brazilian and Chinese populations have observed that the polymorphism could possibly be linked to increased degradation of the TMJ. Luo et. al. conducted a study in 141 Chinese patients in which they observed that individuals with the $2 \mathrm{G}$ genotype were 1.91 times more likely to develop ADDwoR in patients with and without temporomandibular osteoarthritis. For this reason, special attention and care must be given to patients with this genotype who also suffer from ADDwoR or osteoarthritis, given the association between this polymorphism and increased MMP1 activity, which leads to increased catabolism of articular fibrocartilaginous tissue and degradation (12). Planello et. al. (11), also conducted a study in Brazilian individuals, in which, patients with a homozygous $2 \mathrm{G} / 2 \mathrm{G}$ genotype were 2.47 times more likely to develop degradation of the TMJ. In Accordance with this study, where carriers of the $2 \mathrm{G}$ allele had almost 2fold risk, further, individuals with the homozygous $2 G / 2 \mathrm{G}$ genotype could be 6.3 times more likely to develop DDWR, and 5.7 times greater in the dominant model compared to the control group. Lastly, since the $2 \mathrm{G}$ allele was twice as prevalent in the study population compared to the controls, its presence may be a risk factor for the development of DDWR in this population from western Mexico.

No association was observed between the studied symptoms and the polymorphism, perhaps due to the sample size of subgroups when separated by clinical characteristics.

The limitations of this study were that the serum levels of MMP1 were not measured and the damage was not confirmed by radiological examination.

This polymorphism is associated with the development of DDWR in the group of patients from western Mexico. The presence of the $2 \mathrm{G}$ allele could be considered as a risk factor for the development of DDWR in this western Mexican population.

\section{Resumo}

0 deslocamento anterior do disco com redução (DADR) é considerado um dos distúrbios mais comuns na articulação temporomandibular (ATM), com prevalência de $41 \%$ em adultos. As metaloproteinases da matriz desempenham um papel importante na degradação da ATM e o polimorfismo 1607 1G/2G da metaloproteinase da matriz 1 (MMP1) aumenta a expressão local da MMP1, levando à degradação acelerada da matriz extracelular. 0 objetivo deste estudo foi avaliar a associação entre o polimorfismo 1607 1G/2G do gene MMP1 e a DADR em um grupo de indivíduos mexicanos do oeste do México. Um total de 67 indivíduos não relacionados, com idades entre 18 e 36 anos, de ambos os sexos, foram incluidos neste estudo. Os participantes do estudo com DADR foram obrigados a cumprir os Critérios de Diagnóstico de Pesquisa para Disfunções Temporomandibulares (CDP/DTM), enquanto um segundo grupo controle de 90 individuos sem DADR também foi incluido. Ambos os grupos tinham ascendência paterna e materna (avós) da mesma região geográfica e étnica. Os genótipos foram determinados pela técnica de nested PCR. o polimorfismo $1 \mathrm{G} / 2 \mathrm{G}$ foi encontrado em $68,7 \%$, seguido por $2 \mathrm{G} / 2 \mathrm{G}$ em $25,4 \%$ e $1 \mathrm{G} / 1 \mathrm{G}$ em $6,0 \%$ do grupo de casos. Enquanto a prevalência no grupo controle foi de $55,5 \%$ para o polimorfismo $1 \mathrm{G} / 2 \mathrm{G}$, $26,6 \%$ para $1 \mathrm{G} / 1 \mathrm{G}$ e $17,7 \%$ para $2 \mathrm{G} / 2 \mathrm{G}$. Foi encontrada uma associação entre o alelo $2 \mathrm{G}$ do polimorfismo $16071 \mathrm{G} / 2 \mathrm{G}$ do gene $M M P 1$ e a presença de DADR nos pacientes do oeste do México.

\section{References}

1. Greene CS: A new science information statement on TMDs approved by the American Association for dental research - March 2010. Management of patients with TMDs: A New "Standard of care." Int J Prosthodont 2010;23:190-191.

2. Facial Pain Statistics. Data \& statistics. national institute of dental and craniofacial research. (s.f.). Latest access Novemebr 6, 2019, de https://www.nidcr.nih.gov/research/data-statistics/facial-painNational Institute of Dental and Craniofacial Research. Facial Pain. http://www. nidcr.nih.gov/DataStatistics/FindDataByTopic/FacialPain/

3. De-Melo Júnior PC, Aroucha JMCNL, Arnaud M, Lima MGdS, Gomes SGF, Ximenes $\mathrm{R}$, et al. Prevalence of TMD and level of chronic pain in a group of Brazilian adolescents. PLOS ONE 2019;14:e0205874.

4. Ohrbach R, Dworkin SF. The evolution of TMD diagnosis: past, present, future. J Dent Res 2016;95:1093-1101.

5. De-Melo PC, Coelho-Netto JM, Arnaud M, De-Souza MG, Farias-Gomes $S G$, Ximenes $R$, et al. Prevalence of TMD and level of chronic pain in a group of Brazilian adolescents. PLOS ONE 2019;8:1-13

6. Marpaung $C$, van Selms MKA, Lobbezoo F. Temporomandibular joint anterior disc displacement with reduction in a young population: Prevalence and risk indicators. Int J Paediatr Dent 2018;1-8.

7. Poluha RL, De la Torre-Canales G, Costa YM, Grossmann E, Bonjardim LR, Rodrigues-Conti PC. Temporomandibular joint disc displacement with reduction: a review of mechanisms and clinical presentation, J Appl Oral Sci 2019;27:e20180433.

8. Miernik M, Wieckiewicz W. The basic conservative treatment of temporomandibular joint anterior disc displacement without reduction review. Adv Clin Exp Med 2015, 24, 4, 731-735.

9. Casanova-Rosado JF, Medina-Solís CE, Vallejos-Sánchez AA, CasanovaRosado AJ, Hernández-Prado B, Ávila-Burgos L. Prevalence and associated factors for temporomandibular disorders in a group of Mexican adolescents and youth adults. Clin Oral Invest 2006;10:42-49.

10. Perotto JH, De Alcantara-Camejo F, Duarte-Doetzer A, Almeida LE, 
Azevedo $\mathrm{M}$, Olandoski $\mathrm{M}$, et al. Expression of MMP-13 in human temporomandibular joint disc derangement and osteoarthritis. J Craniomand Sleep Prac 2017:1-6.

11. Souza AP de, Line SRP. The biology of matrix metalloproteinases. Rev FOB 2002;10:1-6

12. Srinivas R, Sorsa $T$, Tjäderhane L, Niemi E, Raustia A, Pernu H, Salo T. Matrix metalloproteinases in mild and severe temporomandibular joint internal derangement synovial fluid. Oral Surg Oral Med Oral Pathol Oral Radiol Endod. 2001;91:517-525.

13. Marques-Ferreira L, Benevides-Moura IF, Seabra-Barbosa GA, GomesPereira HS, dos Santos-Calderon P. Do matrix metalloproteinases play a role in degenerative disease of temporomandibular joint? A systematic review. J Craniomand Sleep Prac 2014;0:0

14. Naqvi T, Doung $\Pi$, Hashem $G$, ShigaM, Ahang Q, Kapila S. Relaxin's induction of metalloproteinases is associated with the loss of collagen and glicosaminoglycans in sinovial joint fibrocartilaginous explants. Arthtritis Res Ther 2005;7:R1-R11

15. Arakaki PA, Marques MR, Santos MC. MMP-1 polymorphism and its relationship to pathological processes. J Biosci 2009;34:313-320.

16. Rutter JL, Mitchell TI, Buttici G, Meyers J, Gusella JF, Ozelius $\amalg$ et al. A single nucleotide polymorphism in the matrix metalloproteinase-1 promoter creates an ETS binding site and augments transcription 1. Cancer Research 1998;58:5321-5325, December

17. Planello AC, Campos MIG, Meloto CB, Secolin R, Rizatti-Barbosa CM, Line SRP, de Souza AP. Association of matrix metalloproteinase gene polymorphism with temporomandibular joint degeneration. Eur J Oral Sci 2011;119:1-6.

18. Luo $\mathrm{S}$, Deng $\mathrm{M}$, Long $\mathrm{X}, \mathrm{Li} J, \mathrm{Xu}$ L, Fang W. Association between polymorphism of MMP-1 promoter and the susceptibility to anterior disc displacement and temporomandibular joint osteoarthritis. Arch Oral Biol 2015;60:1675-1680.

19. Schiffman E, Ohrbach R, Truelove E, Look J, Anderson G, et al. Diagnostic criteria for temporomandibular disorders (DC/TMD) for clinical and research applications: recommendations of the international RDC/TMD consortium network and orofacial pain special interest group. J Oral Facial Pain Headache. 2014;28:6-27.

20. Naeije M, Te Veldhuis AH, Te Veldhuis EC, Visscher CM, Lobbezoo F.Disc displacement within the human temporomandibular joint: a systematic review of a 'noisy annoyance'. J Oral Rehabil 2013;40:139-158.

21. Miller SA, Dykes DD, Polesky HF. A simple salting out procedure for extracting DNA from human nucleated cells. Nucleic Acids Res $1988 ; 11 ; 16: 1215$

22. Kaur H, Datta K. J. Prosthodontic management of temporomandibular disorders Indian. Prosthodont Soc 2013;13:400-405

23. Manfredini D, Arveda N, Guarda-Nardini L, Segù $M$, Collesano V. Distribution of diagnoses in a population of patients with temporomandibular disorders. Oral Surg Oral Med Oral Pathol Oral Radiol 2012;114:e35-e41.

24. Pimenta L, Machado S, de Góis-Nery, Rodrigues-Leles C, Batista de Macedo Nery, Okeson PJ. The prevalence of clinical diagnostic groups in patients with temporomandibular disorders. J Craniomand Prac 2009;27194-27199.

25. Hongxing L, Astrom AN, List T, Nilsson IM, Johansson A. Prevalence of temporomandibular disorder pain in Chinese adolescents compared to an age-matched Swedish population. J Oral Rehabil 2016;43:241-248.

26. Manfredini D, Restrepo C, Diaz-Serrano K, Winocur E, Lobbezoo F. Epidemiology of bruxism in adults: a systematic review of the literature. J Oral Rehabil 2013;40:631-642.

27. Porto De Toledo, Miron SF, Porporatti AL, Mezzomo LA, Peres MA, Carlos Flores-Mir C, De Luca Canto G. Prevalence of otologic signs and symptoms in adult patients with temporomandibular disorders: a systematic review and meta-analysis. Clin Oral Inv 2017;21:597-605

Received July 2, 20192019

Accepted November 6, 2019 